\title{
Consumption Motivation of Limited Edition Product in Reselling Open Market
}

\author{
Woodong Kim and Boyoung Kim * \\ Seoul Business School, Seoul School of Integrated Sciences and Technologies (aSSIST), Seoul 03767, Korea; \\ woodong.kim@dae-yeon.co.kr \\ * Correspondence: bykim2@assist.ac.kr; Tel.: +82-70-7012-2728
}

Received: 6 October 2020; Accepted: 5 November 2020; Published: 6 November 2020

\begin{abstract}
Recently, the phenomenon of purchasing limited edition products has been spreading rapidly in the reselling open market. As various technologies are introduced in the era of the fourth industrial revolution, platform-centered digital distribution has become popular and consumers buy limited edition products as a reflection of their various access behaviors to satisfy their social needs for reselling and not out of mere curiosity or personal preference. Accordingly, this study includes a survey conducted among 564 consumers of limited edition products who were leading the consumer-centered reselling open markets in Korea. Specifically, five factors of limited edition products consumption motivation-functional, emotional, social, epistemic, and economic - are defined, and how these factors affect the continuous consumption attitudes of consumers with such active consumption attitudes as a medium is considered. The analysis result shows that emotional factors are not significant as a motivation factor to limited product consumption while economic factors had a significant effect on the behavior of continued resale product consumption. This result clearly indicates that while consumers sometimes purchased limited edition products merely out of functional, social, and epistemic motivation, acquiring economic value through reselling in the customer to customer open market was also an important consumption motivation.
\end{abstract}

Keywords: reselling open market; limited edition product; consumption motivation; active customer; innovative behavior

\section{Introduction}

The reselling open market of limited products, which used to reflect the culture of minority enthusiast groups, is growing rapidly, mainly among young consumers in their 20 s to 30 s $[1,2]$. In particular, as economic gains are realized through reselling and limited product marketing is increasing among enterprises aiming at the limited edition product market, this phenomenon is spreading more rapidly. "Reselling" is an act of consumers buying edition products purchased in the primary market and then reselling them in secondary markets such as second-hand trading websites, flea markets, and person-to-person trading websites at higher prices than the original prices.

Major items handled in reselling open markets include sneakers, luxury goods, art toys, and performance tickets, and the scope of such items being traded is increasing. According to thredUP, the biggest second-hand clothing resale company, the global resale market scale is estimated to be about 48 trillion won this year. GlobalData Market Sizing and Growth Estimate also predicts that in the following 5 years, while the retail market expansion rate is as low as $2 \%$, the resale market will increase as much as $49 \%$.

For example, regarding the sneakers resale market where consumer reselling is most active, Cowen \& Company, a U.S. investment bank, estimates that the scale of the global sneakers resale market was 2 billion US dollars last year. StockX, the US sneakers reselling platform founded in 2015, 
introduced the concept of a stock market in this area so that people could trade sneakers just like stocks. After only 5 years since its foundation, the corporate value of this company is now estimated to be 1 trillion won.

As a background to the growth of such reselling markets of rare limited edition products, the limited edition marketing strategies of enterprises and technical environments of businesses have changed favorably towards such limited edition product markets. The availability of such products is limited to consumers; therefore, people recognize the value of limited edition products as being relatively high, which is called an epistemic effect [3]. Marketing strategies of enterprises utilizing such epistemic messages have led to the formation of reselling markets aimed at consumers who have already purchased or have yet to purchase limited edition products. Successful experiences of consumers with a strong will to purchase in the purchasing and selling of such products has led to learning effects and to both purchasing and reselling activities of limited edition products.

In resale markets of limited edition products, it is common for consumers to be both purchasers and sellers [4]. With the growth of SNS-based online commerce, increases in platform businesses, and the wide spread of one-man businesses, such various changes in the business environment have provided active support for consumers playing the role of sellers [5]. In particular, in the fourth industrial revolution the "Un-tact" trend is spreading widely in traditional distribution environments with the involvement of various technologies such as IoT and AI. Such market changes also induce consumers to go beyond traditional acts of purchasing and participate directly in markets as a type of producer [1,6,7]. As emphasized by Goncalves et al. [8], contemporary consumers are showing consumption behaviors that are new and original or pursue new values, outgrowing the existing customer value chain (CVC).

Enterprises are no longer the only producer in markets. They need to understand the conditions of markets where consumers both purchase and sell as well as consumer trends. In such changing conditions, enterprises need to design new strategies accordingly $[9,10]$. This study examines trends in the limited edition product reselling market and consumption motivation factors of consumers buying limited edition products. In addition, this study verifies the effects of such consumption motivation factors on active and continued consumption behaviors.

As the reselling open market with a dual structure where consumers are also sellers is growing, there are limitations in viewing limited product consumption merely as a nonmainstream culture of enthusiast groups. The market of limited product selling and reselling has begun to form an industry with the involvement of specialized enterprises and platforms. Furthermore, it has already been established as a large-scale business in the global market [11,12]. Therefore, there is an urgent need for enterprises to understand the behavior and culture of the buying of limited edition products by consumers. This study verifies consumption motivation factors related to the reselling behavior of consumers as well as major factors inducing their attitudes and continuous behaviors in order to present significant implications to enterprises involved in the changing distribution market.

\section{Theory and Research Propositions Development}

\subsection{Consumption Motivation of Limited Edition Products}

Consumption motivation is defined as a reason for an individual to purchase certain goods or services in order to satisfy such person's own needs [13]. Tauber [14] states that consumers may shop for actual purchases, but there could be various intentions and motives inducing shopping. Delbridge and Edwards [15] analyzed consumers visiting shops and classified consumption motivation into hedonic, leisure, and experiencing motivation. Much research is being conducted into both consumer needs, as such needs become more varied, and consumer hedonic or emotional values, as such values are being regarded as important.

In the context of self-determination concepts, such consumption motivation is defined as an autonomous intention distinguished from a controlled intention regarding human behaviors [16]. 
In the theory of self-determination, human behaviors are classified into external motivation and internal motivation. Human motivation is classified into a type of acting in response to external restrictions with no self-determination (external regulation or external motivation) and a type of acting with selected regulations in line with a person's own behavior goals (integrated regulation or internal motivation).

As a major variable related to the prediction of consumer behavior, consumption motivation has been researched in the area of persuasive communication [17]. Major examples of motivation types are hedonic motivation and practical motivation. Consumption motivation is a basis for a determination on the relative importance of various attributes in a series of procedures of commodity purchase of a person that depend on personal pursuits. It is classified mainly into practical motivation and hedonic motivation [18]. Purchase out of practical motivation is induced by cognitive power. It is purpose-oriented and substantial [19-21]. In contrast, purchase out of hedonic motivation is to satisfy needs for enjoyment, fantastic things, and fun things [22,23].

Many studies verifying the relationship between purchase motivation and purchase behavior present various definitions of purchase motivation factors in consideration of consumption motivation and psychological aspects. Tauber [14], for example, presents the following factors of social motivation: social experience with others, communication with others, friendliness with companions, status and authority, and enjoyment. Bearden and Rose [24] present seven factors: expected utility, role playing, bargaining, optimized choice, belonging, authority, and stimulation. Many studies examined the effects on various factors such as socializing and solidarity motivation [25], product information acquisition and variety pursuit motivation [26], self-satisfaction and value motivation [27], variety pursuit and word-of-mouth [28], and purchase frequency [29]. Jang et al. [30] present such factors as economic consumption motivation, variety pursuit motivation, and hedonic consumption motivation. La Rocca [31] presents factors such as entertainment, informativeness, convenience, and economic efficiency. Ortiz et al. [32] analyzed social motivation, functional motivation, amusement motivation, and economic motivation.

Particularly in the case of consuming limited edition products, previous studies suggest that when potential consumers are notified of the limitedness, they tend to buy more and more actively [33]. According to previous studies, the biggest reason for this phenomenon is that consumers purchasing limited edition products gain economic or psychological rewards by winning such implicit competitions with other consumers [34,35]. In addition, as commodities are a means of communication with surrounding people, owning and using rare products make the owners the envy of others, which as a result satisfies social needs [36]. Thus, in the case of limited edition resale products, rather than ordinary products, the learning effect from past purchasing experiences of limited edition products affects consumers and makes them expect that they can buy rarer and better quality products. Such expectation may provide further motivation for consumers to buy products, which is called "extraordinary consumption" [37-39].

Rarity and exclusivity of valuable products satisfy the needs of consumers for owning unique items, and consumers with such needs that are greater than those of others tend to avoid buying popular products in order to differentiate themselves from other consumers, which is called the snob effect [40]. Consumers tend to prefer a creative choice of items that are acceptable to others but that are not ordinary, a personal choice of pursuits that others do not prefer, and a minority choice of items that are acceptable to others but that are only minorities out of avoidance of similarities. Such tendencies affect the behavior of consuming limited edition products $[41,42]$.

In summary, based on relevant previous studies, this study presents five consumption motivation factors, as shown in Table 1, that affect attitudes of resale product consumption and goals of such consumption-functional, emotional, social, epistemic, and economic. In addition, this study examines the effects of such consumption motivation factors on consumption attitudes and continuous consumption behaviors. 
Table 1. Previous studies on consumption motivation factors.

\begin{tabular}{|c|c|c|}
\hline Factor & Content & Previous Study \\
\hline Functional motivation & $\begin{array}{l}\text { Consumption motivation factors } \\
\text { affecting the achievement of } \\
\text { consumption goals such as } \\
\text { practicality, convenience, } \\
\text { and optimization. }\end{array}$ & $\begin{array}{c}\text { Malaviya and Brendl [17] } \\
\text { Hair and Ozcan [20] } \\
\text { Gierl and Huettl [25] }\end{array}$ \\
\hline Emotional motivation & $\begin{array}{l}\text { Consumption motivation factors } \\
\text { affecting the achievement of } \\
\text { consumption goals such as } \\
\text { pleasure, amusement, recreation, } \\
\text { and self-satisfaction. }\end{array}$ & $\begin{array}{c}\text { Hirschman [21] } \\
\text { Simonson and Nowlis [26] } \\
\text { Ku et al. [27] }\end{array}$ \\
\hline Social motivation & $\begin{array}{l}\text { Consumption motivation factors } \\
\text { affecting the achievement of } \\
\text { consumption goals such as social } \\
\text { consolidation, belonging and } \\
\text { authority, and a sense } \\
\text { of superiority. }\end{array}$ & $\begin{array}{l}\text { Cheema and Kaikati [28] } \\
\text { Jang et al. [30] } \\
\text { Kalpana and Shibu [35] }\end{array}$ \\
\hline Epistemic motivation & $\begin{array}{l}\text { Consumption motivation factors } \\
\text { affecting the achievement of } \\
\text { consumption goals such as rarity, } \\
\text { uniqueness, and value of owning. }\end{array}$ & $\begin{array}{l}\text { Roy and Sharma [23] } \\
\text { Ortiz et al. [32] } \\
\text { Choi et al. [34] }\end{array}$ \\
\hline Economic motivation & $\begin{array}{l}\text { Consumption motivation factors } \\
\text { affecting the achievement of } \\
\text { consumption goals such as price, } \\
\text { benefit, effectiveness. }\end{array}$ & $\begin{array}{l}\text { Hair and Ozcan [20] } \\
\text { Petty et al. [22] } \\
\text { Lerner et al. [29] }\end{array}$ \\
\hline
\end{tabular}

\subsection{Research Model}

This study includes empirical analysis on which of the consumption motivation factors of consumers, with regard to rare resale products, has a more significant effect on continued consumption attitudes with their activeness in consumption behaviors as a medium. To this end, the conceptual model of this study was designed as in Figure 1 on the basis of research hypotheses derived from previous studies. This study examines the following five factors affecting consumption motivation of rare resale products: "functional factor", "emotional factor", "social factor", "epistemic factor", and "economic factor". Additionally, this study verifies the causal relationship between such factors and active consumption attitudes, certain factors that have greater significance in causing activeness, and the effects of such active consumption attitudes on behaviors pursuing continuous consumption of rare resale products.

As pointed out by the theory of goal achievement motivation, consumers determine the level of motivation and the level of achievement on the basis of their goals. In other words, they practice behaviors of consumption with their special motivation and goal of consumption [36]. For this reason, consumers prioritize various consumption purposes from the perspective of active consumers who plan their own consumptions and obtain satisfaction from such behaviors and tend to seek ways of the highest efficiency. According to previous studies, if the level of motivation is low in situations of consumption, consumers tend to lower their expectation of goal achievement as well as emotional responsiveness and the will of consumption [43]. As the goals are evident on the part of consumers, expectation and consumption motivation factors become more influential. As the relevance to personal profits is closer, the positive pursuit of consumption goals is induced, which leads to more active behaviors of consumption. 


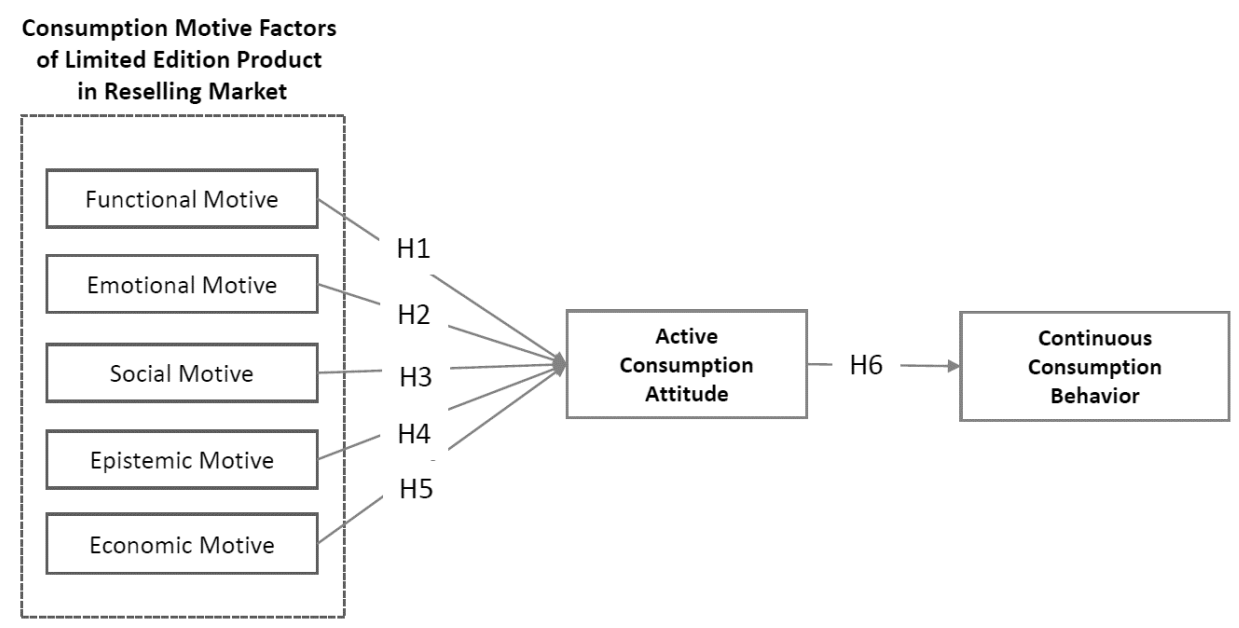

Figure 1. Research Model.

According to Prentice et al. [44], emotional and social consumption motivation factors are the very basis for goal orientedness and more active consumption attitudes toward the consumption process. The will of consumption indicates the effort required to achieve personal goals. It is a determinant of the extent of behaviors in the consumption process and an act of putting efforts into planning and selecting appropriate behaviors [45]. According to such theories of consumption process behaviors, consumers determine their level of willingness to consume depending on their consumption motivation and expectation and take action actively to achieve consumption goals [46]. In addition, the consumption attitudes of consumers represent their personal status and self-determination between personal knowledge and behavior in actual purchases $[47,48]$. For this reason, such attitudes that arise from the psychological perception and behavioral intention of purchasing products or services [49] and active attitudes toward consumption in reflection of various factors of consumers such as perceived values, personal innovation, experience, and learning induce acts of pursuing consumption goals and stimulate the will to purchase [50].

Particularly when it comes to buying limited edition products, unlike the attitudes of consumers in common consumption behaviors, consumer consumption attitudes are strengthened by the needs of consumers intending to buy limited edition products as well as unique consumption factors such as taking risks of buying such resale products and being willing to accept innovative elements [51,52]. Consumer behaviors related to resale products are not limited to the traditional consumer roles and also involve the role of sellers [53]. Thus, self-confidence factors such as trust, belief, and confidence in their own ability and judgment play a key role in this regard. Legendre et al. [54] defined self-confidence as the ability to put up with perceived dangers, viewing it as one of the representative psychological characteristics of purchasers. Such self-confidence in purchasing affects the strong will of consumers to purchase on the basis of relevant factors such as information acquisition and reviews of others [55]. As such, the self-confidence of consumers in their own purchases and consumption behavior factors such as personal innovation are determinants in this market of rare resale products, which is unlike the common behaviors in the market of popular resale products. Thus, consumer participation and activeness in consumption are important factors for decisions on and consumption attitudes toward limited edition products.

Accordingly, this study presents the following hypotheses on the assumption that the factors of rare resale products presented above-functional, emotional, social, epistemic, and economic consumption motivation-have positive effects $(+)$ on active consumption attitudes;

Hypothesis 1 (H1). For limited edition product consumption motivation in reselling market, functional factors have positive effects $(+)$ on active consumption attitudes. 
Hypothesis 2 (H2). For limited edition product consumption motivation in reselling market, emotional factors have positive effects (+) on active consumption attitudes.

Hypothesis 3 (H3). For limited edition product consumption motivation in reselling market, social factors have positive effects (+) on active consumption attitudes.

Hypothesis 4 (H4). For limited edition product consumption motivation in reselling market, epistemic factors have positive effects $(+)$ on active consumption attitudes.

Hypothesis 5 (H5). For limited edition product consumption motivation in reselling market, economic factors have positive effects $(+)$ on active consumption attitudes.

Consumption behaviors assume that there are expected or planned future behaviors of consumption. Such behaviors reflect the possibility that the conviction and attitude of customers will lead to certain acts such as purchasing [56]. For consumption behaviors, intentions are divided mainly into the intention of purchase and the intention of recommendation. The intention of purchase implies the tendency of behavior for consumers to buy certain products or services. This is a determinant factor regarding the consumption of products and services [57,58]. In the context of consumer behavior intentions, the intention of recommendation involves a series of plans, actions, and procedures of consumers to deliver views, positive or negative, to others based on their experience regarding certain products or services [59].

Consumption behaviors are related to the intention of maintaining the relationship between consumers and brands [60]. The past use experience of users affects their intention of continued use; it can be one of the most important factors for consumers to maintain their relationship with a certain brand and for enterprises to create long-term business achievements [61]. Continuous consumption attitudes are acts practiced after a product or service has been accepted [62]. Such attitudes imply the possibility for consumers to use a service or product of the same provider repeatedly in the future. In other words, continuous consumption attitudes may be defined as the extent to which consumers want to use the purchased product or service again [63].

Consumers may show consistent attitudes or behaviors depending on the level of satisfaction with the consumption process. After all, as consumers have more positive experiences in a consumption process, it is more likely that they continue to use purchased items [64,65]. As emphasized by Pion et al. [66], the approach to attitudes of purchase focuses on intentions of future purchase or brand preferences. It is based on the measurement of favorable attitudes towards certain products or services and on consumers' preference and psychological commitment. Furthermore, these consumers' examination is related to the variables of customer loyalty improvement. In particular, consumption attitudes develop based on the past experience of consumers of using products or services and have a significant effect on future decisions. Thus, examining such attitudes plays an important role in consumption behavior research $[67,68]$. Such elements are determinant factors of consumer criteria and general evaluation of consumption choices [69].

With regard to limited edition products, consumers may buy such products merely to use them, but also the purchaser often tends to act as a reseller. Accordingly, analyzing repurchase intentions or trends of continuous consumption attitudes merely based on the level of purchase satisfaction has limitations in terms of limited edition product consumption behaviors [70,71]. Thus, on the basic assumptions of emotional satisfaction with purchasing highly rare limited edition products, positive experience of consumption behaviors in terms of social and economic values, and characteristics and motivations of limited edition product purchases that may involve future values because they can be resold, this study presents the following hypothesis regarding the expectation that resulting active consumption attitudes will lead to continued consumption activity; 
Hypothesis 6 (H6). Active consumption attitudes toward rare resale products have positive effects (+) on continuous consumption behaviors.

\section{Research Methodology}

\subsection{Sample Description}

To conduct the survey sample, this study used the customer database of "Daeyeon-retail", a professional distribution company. The database includes customer information about the selling of limited edition products; shoes, sneakers, sportwear, and sports-related accessories. Respondents who had an experience of purchasing limited edition products within the reselling market in South Korea were selected and were estimated to be around 5100 million people. Additionally, the male population of resellers in South Korea is the bigger than female one based on the database. The online survey period was 6 days; that is, from 14 to 19 June 2020. A total of 682 copies of the questionnaire were collected and, among them, 564 copies were used in the final analysis.

Among survey respondents, $82.8 \%$ were male and $17.2 \%$ were female; $3.4 \%$ were under 20 , $30.7 \%$ were in their $20 \mathrm{~s}, 47.9 \%$ were in their $30 \mathrm{~s}$, and $16.5 \%$ were in their $40 \mathrm{~s}$. Thus, the majority of consumers were in their 20s to 30s. For academic background, 35.5\% were high school graduates and $57.3 \%$ were college graduates. For occupation, $61.5 \%$ were employees, $14.7 \%$ self-employed persons, $10.6 \%$ professionals, and $9 \%$ students. For the major purpose of buying limited edition products, $77.5 \%$ intended to use them personally, $18.1 \%$ wanted to collect them, and 3.5\% wanted to resell them. For frequency of purchase, $43.3 \%$, the largest percentage, would buy limited edition products 3 times or less a year, $24.5 \% 4$ to 6 times, $8 \% 7$ to 9 times, and $24.3 \% 10$ or more times. A large percentage of consumers would frequently buy limited edition products in reselling market (Table 2).

\subsection{Research Instrument}

Structural definitions and measurement items of each variable based on previous studies are shown in Table 3. The measuring questions in the questionnaire were designed in a 5-point Liker-type scale ( $1=$ not at all, $5=$ very much). The consumption motivation factors of the independent variable and limited edition resale products were "functional", "emotional", "social", and "epistemic", which were selected based on the consumption motivation variables of consumers with regard to limited edition products and resale products as suggested by Zang [51], Lee and Faber [52], and Lee et al. [55]. Particularly, this study added an "economic" variable as an independent factor because the customer's self-reselling behavior of limited edition products on online platforms has been growing recently. Moreover, customer sellers and online startups have developed into a reselling business of limited edition products in a person-to-person market. In these backgrounds, the customer's consumption behavior of limited edition products can be related to economic value. This study used the economic variable and survey items included on the basis of the research of Guercini et al. [49] and Bazhanov et al. [61]. The parameter of "active consumption attitudes" is based on previous studies of Libai et al. [59], Martin and Jin [63], and Vargo [72]. The dependent variable "continuous consumption behavior" is based on the research of Wong et al. [65] and Pino et al. [66]. After factor analysis, a total of 20 variables were selected as the final measuring factors.

\subsection{Statistical Methods}

Data collected by the questionnaire survey method were analyzed in using various statistical methods. Reliability analysis was used Cronbach's alpha coefficients. Primary data were submitted to correlation analysis in order to check for negative or low correlations. The structural equations model was conducted for statistical testing of the propositions and was tested using the fit indices proposed by Hernaus et al. [73]. SPSS 26.0 was utilized for technical statistics, regularity of demographic characteristics, and factor analysis. The confirmatory factor analysis and path analysis of the structural equation model were analyzed using AMOS 26.0. 
Table 2. Demographic information of survey participants.

\begin{tabular}{|c|c|c|c|}
\hline & Classification & Frequency & Percentage \\
\hline \multirow{3}{*}{ Gender } & Male & 467 & 82.8 \\
\hline & Female & 97 & 17.2 \\
\hline & Total & 564 & 100 \\
\hline \multirow{6}{*}{ Age } & Less than 20 & 19 & 3.4 \\
\hline & $20-29$ & 173 & 30.7 \\
\hline & 30-39 & 270 & 47.9 \\
\hline & $40-49$ & 93 & 16.5 \\
\hline & 50 or older & 9 & 1.6 \\
\hline & Total & 564 & 100 \\
\hline \multirow{4}{*}{ Education level } & High school graduate & 200 & 35.5 \\
\hline & College graduate & 323 & 57.3 \\
\hline & Graduate school or higher & 41 & 7.3 \\
\hline & Total & 564 & 100 \\
\hline \multirow{6}{*}{ Occupation } & Inoccupation & 23 & 4.1 \\
\hline & Self-employed person & 83 & 14.7 \\
\hline & Professional & 60 & 10.6 \\
\hline & Employee & 347 & 61.5 \\
\hline & Student & 51 & 9.0 \\
\hline & Total & 564 & 100 \\
\hline \multirow{5}{*}{$\begin{array}{l}\text { Purpose of } \\
\text { purchase }\end{array}$} & To make a collection & 102 & 18.1 \\
\hline & To resell them & 20 & 3.5 \\
\hline & To use them personally & 437 & 77.5 \\
\hline & Etc. & 5 & 0.9 \\
\hline & Total & 564 & 100 \\
\hline \multirow{5}{*}{$\begin{array}{l}\text { Purchase time } \\
\text { per year }\end{array}$} & 3 or less & 244 & 43.3 \\
\hline & 4-6 times & 138 & 24.5 \\
\hline & $7-9$ times & 45 & 8.0 \\
\hline & 10 or more times & 137 & 24.3 \\
\hline & Total & 564 & 100 \\
\hline
\end{tabular}


Table 3. Variables and survey items.

\begin{tabular}{|c|c|c|}
\hline Variable & Survey Items & References \\
\hline $\begin{array}{l}\text { Functional } \\
\text { Motivation }\end{array}$ & $\begin{array}{l}\text { I can obtain goods that I wanted within a } \\
\text { short time by purchasing limited edition } \\
\text { products in reselling market. } \\
\text { It is effective to purchase limited edition } \\
\text { products in reselling market. } \\
\text { It is convenient to purchase limited } \\
\text { edition products in reselling market. }\end{array}$ & \\
\hline $\begin{array}{l}\text { Emotional } \\
\text { Motivation }\end{array}$ & $\begin{array}{l}\text { It is joyful to purchase limited edition } \\
\text { products in reselling market. } \\
\text { I feel comfortable when buying limited } \\
\text { edition products in reselling market. } \\
\text { I feel happy when when buying limited } \\
\text { edition products in reselling market. }\end{array}$ & Zang [51], \\
\hline $\begin{array}{c}\text { Social } \\
\text { Motivation }\end{array}$ & $\begin{array}{l}\text { It is joyful to purchase limited edition } \\
\text { products in reselling market. } \\
\text { I feel comfortable when buying limited } \\
\text { edition products in reselling market. } \\
\text { I feel happy when when buying limited } \\
\text { edition products in reselling market. }\end{array}$ & $\begin{array}{l}\text { Lee and Faber [52] } \\
\text { Lee et al. [55]. }\end{array}$ \\
\hline $\begin{array}{l}\text { Epistemic } \\
\text { Motivation }\end{array}$ & $\begin{array}{l}\text { Buying limited edition products in } \\
\text { reselling market helps me to become } \\
\text { famous and improve my image. } \\
\text { Many interact in the process of limited } \\
\text { edition products in reselling market. } \\
\text { I feel a sense of superiority and } \\
\text { self-confidence when } \\
\text { buying limited edition products in } \\
\text { reselling market. }\end{array}$ & \\
\hline
\end{tabular}

I buy limited edition products in reselling market since I can buy them at a low price.

I buy limited edition products in reselling

Economic

Motivation

$$
\text { market since it has advantages }
$$
in bargaining.

I buy limited edition products in reselling market since I can resell them at

$$
\text { higher price. }
$$

Guercini et al. [49]

Bazhanov et al. [61]

I am willing to spend much time to buy limited edition products in reselling market.

Active Consumption Attitude
I am willing to bear a lot of cost to buy limited edition products in reselling market.

I collect information frequently to be able to buy edition products in reselling market.
I will continue to buy edition products in

$$
\text { reselling market. }
$$

I will recommend surrounding people to buy edition products in reselling market.
Libai et al. [59]

Martin and Jin [63]

Vargo [72]
Continuous Consumption Behavior 


\section{Data Analysis and Research Findings}

\subsection{Reliability and Validity}

The convergent validity of measurement items was assessed based on the factor loading, average variance extracted, and composite reliability [74]. Accordingly, the average variance extracted (AVE) value and correlation coefficient of latent variables were examined in order to verify the discriminant validity. The result showed that the value of the AVE square root calculated from each latent variable was larger than the correlation coefficient of other variables (Table 4).

Table 4. Correlation Matrix and average variance extracted (AVE).

\begin{tabular}{|c|c|c|c|c|c|c|c|c|c|}
\hline Variable & CR & AVE & FM & EM & SM & EpM & EcM & ACA & CСB \\
\hline $\begin{array}{l}\text { Functional } \\
\text { motive (FM) }\end{array}$ & 0.817 & 0.784 & 0.764 & & & & & & \\
\hline $\begin{array}{c}\text { Emotional } \\
\text { Motive (EM) }\end{array}$ & 0.841 & 0.636 & 0.622 & 0.81 & & & & & \\
\hline $\begin{array}{l}\text { Social motive } \\
(\mathrm{SM})\end{array}$ & 0.834 & 0.735 & 0.417 & 0.518 & 0.859 & & & & \\
\hline $\begin{array}{l}\text { Epistemic } \\
\text { motive } \\
(\text { EpM) }\end{array}$ & 0.878 & 0.651 & 0.536 & 0.556 & 0.576 & 0.801 & & & \\
\hline $\begin{array}{c}\text { Economic } \\
\text { motive }(\text { EcM) }\end{array}$ & 0.811 & 0.616 & 0.443 & 0.518 & 0.448 & 0.551 & 0.81 & & \\
\hline $\begin{array}{c}\text { Active } \\
\text { Consumption } \\
\text { Attitude } \\
\text { (ACA) }\end{array}$ & 0.854 & 0.677 & 0.479 & 0.535 & 0.451 & 0.505 & 0.528 & 0.817 & \\
\hline $\begin{array}{l}\text { Continuous } \\
\text { Consumption } \\
\text { Behaviour } \\
\text { (CCB) }\end{array}$ & 0.798 & 0.645 & 0.481 & 0.512 & 0.491 & 0.533 & 0.573 & 0.567 & 0.80 \\
\hline
\end{tabular}

As shown in Table 5. the analysis result shows that the factor loading was 0.699 to 0.890 , and the values of $t$ were all at least 10.0, which is statistically significant. The average variance extracted was between 0.614 and 0.745 , and Cronbach $\alpha$ was between 0.743 and 0.894 . Hence, the composite validity was secured. From an analysis of the fitness of the measurement model, $\chi^{2}(\mathrm{df})$ was 369.460 and $\chi^{2} /$ degree of freedom was 2.231. The value of the goodness-of-fit-index (GFI) was 0.931 , the adjusted goodness-of-fit-index (AGFI) 0.912, the normal fit index (NFI) 0.942, and the root mean square error of approximation (RMSEA) 0.061 . Thus the values of the measurement model fitness were all statistically significant [75].

\subsection{Research Propositions Testing}

The fitness of the structural model was verified as shown in Table 6. This study utilized the absolute fitness indexes including $\chi^{2}$ statistics, GFI, AGFI, RMSEA, and increase fit indexes including NFI and comparative fit index (CFI) showing the explanatory power of the model regardless of samples. In general, the research model fitness is viewed as satisfactory when the GFI is at least 0.9 , the AGFI is 0.8 , the root mean square residuals (RMR) that indicate the distribution size unexplainable with models are 0.1 or less, and the value of $\chi^{2}$ divided by the degree of freedom is 5 or smaller [76]. In reference to the fitness criteria, the results showed that $\chi^{2}(\mathrm{df})$ was $461.270(p=000), \chi^{2} /$ degree of freedom was 2.9488, GFI was 0.915, and AGFI was 0.902 (the value is larger than 0.9). The value of RMSEA was 0.061 , that of NFI was 0.917 , and that of CFI was 0.945 . Thus, the explanatory power was proved to be satisfactory. 
Table 5. Results of reliability and convergent validity test.

\begin{tabular}{|c|c|c|c|c|c|c|c|}
\hline Variables & $\begin{array}{l}\text { Measurement } \\
\text { Item }\end{array}$ & $\begin{array}{l}\text { Standard } \\
\text { Load }\end{array}$ & $\begin{array}{l}\text { Standard } \\
\text { Error }\end{array}$ & $\begin{array}{c}t \text {-Value } \\
(p)\end{array}$ & CR & AVE & Cronbach $\alpha$ \\
\hline \multirow{3}{*}{$\begin{array}{l}\text { Functional } \\
\text { motive }\end{array}$} & fun1 & 0.814 & & & \multirow{2}{*}{0.761} & \multirow{2}{*}{0.614} & \multirow{2}{*}{0.757} \\
\hline & fun2 & 0.712 & 0.061 & $15.467^{* * *}$ & & & \\
\hline & fun3 & 0.766 & 0.096 & $11.743^{* * *}$ & & & \\
\hline \multirow{3}{*}{$\begin{array}{l}\text { Emotional } \\
\text { motive }\end{array}$} & emo1 & 0.831 & & & \multirow{3}{*}{0.841} & \multirow{3}{*}{0.676} & \multirow{3}{*}{0.894} \\
\hline & emo2 & 0.803 & 0.045 & $21.204^{* * *}$ & & & \\
\hline & emo3 & 0.795 & 0.045 & $20.939^{* * *}$ & & & \\
\hline \multirow{3}{*}{$\begin{array}{l}\text { Social } \\
\text { motive }\end{array}$} & soc1 & 0.872 & & & \multirow{2}{*}{0.859} & \multirow{2}{*}{0.727} & \multirow{2}{*}{0.830} \\
\hline & soc3 & 0.845 & 0.049 & $19.821^{* * *}$ & & & \\
\hline & $\operatorname{soc} 3$ & 0.801 & 0.056 & $17.809^{* * *}$ & & & \\
\hline \multirow{3}{*}{$\begin{array}{l}\text { Epistemic } \\
\text { motive }\end{array}$} & epi1 & 0.851 & & & \multirow{3}{*}{0.841} & \multirow{3}{*}{0.645} & \multirow{3}{*}{0.856} \\
\hline & epi2 & 0.776 & 0.044 & $20.624^{* * *}$ & & & \\
\hline & epi3 & 0.773 & 0.042 & $20.500 * * *$ & & & \\
\hline \multirow{3}{*}{$\begin{array}{l}\text { Economic } \\
\text { motive }\end{array}$} & eco1 & 0.713 & & & \multirow{3}{*}{0.834} & \multirow{3}{*}{0.649} & \multirow{3}{*}{0.829} \\
\hline & eco2 & 0.916 & 0.066 & $19.302^{* * *}$ & & & \\
\hline & eco3 & 0.787 & 0.063 & $17.584^{* * *}$ & & & \\
\hline \multirow{3}{*}{$\begin{array}{c}\text { Active } \\
\text { Consumption } \\
\text { Attitude }\end{array}$} & aca1 & 0.818 & & & \multirow{3}{*}{0.869} & \multirow{3}{*}{0.745} & \multirow{3}{*}{0.767} \\
\hline & aca2 & 0.817 & 0.051 & $18.197^{* * *}$ & & & \\
\hline & aca3 & 0.831 & 0.052 & $19.960^{* * *}$ & & & \\
\hline \multirow{2}{*}{$\begin{array}{l}\text { Continuous } \\
\text { Consumption } \\
\text { Behaviour }\end{array}$} & $\mathrm{ccb} 1$ & 0.890 & & & \multirow{2}{*}{0.771} & \multirow{2}{*}{0.740} & \multirow{2}{*}{0.743} \\
\hline & ccb2 & 0.699 & 0.051 & $16.848^{* * *}$ & & & \\
\hline
\end{tabular}

(1) Measurement model fit: $\chi^{2}$ (df) 369.460, DF 245, $\chi^{2}$ /degree of freedom 2.231, root mean square residuals (RMR) 0.067, goodness-of-fit-index (GFI) 0.931, adjusted goodness-of-fit-index (AGFI) 0.912, normal fit index (NFI) 0.942, tucker-lewis index (TLI) 0.939, comparative fit index (CFI) 0.956, root mean square error of approximation RMSEA (0.061). (2)* $p<0.05,{ }^{* *} p<0.01,{ }^{* * *} p<0.001$.

The final structural model path coefficient was examined for hypothesis verification, and the consumption motivation factor most influential on active consumption attitudes toward limited edition products was shown to be the economic factor $(t=5.167, p<0.001)$, followed in order by the social factor $(\mathrm{t}=2.703, p<0.01)$, epistemic factor $(\mathrm{t}=2.621, p<0.01)$, and functional factor $(\mathrm{t}=2.713, p<0.05)$. On the other hand, the hypothesis regarding the emotional factor was rejected as it turned out that the role of the consumption motivation factor was not statistically significant with regard to active consumption attitudes.

In addition, active consumption attitudes proved to have a positive $(+)$ effect on continuous consumption behaviors $(t=2.0897, p<0.05)$; thus, the corresponding hypothesis was adopted. Direct and indirect effects were analyzed through Sobel testing, and it was shown that the five consumption motivation factors all had direct and significant effects on continuous consumption behaviors. Accordingly, consumption motivation factors of limited edition products in the resale markets could affect the continuity of consumer consumption behaviors directly without the need for the involvement of active consumption attitudes. 
Table 6. Results of hypothesis test.

\begin{tabular}{|c|c|c|c|c|c|}
\hline & Hypothesis & $\begin{array}{l}\text { Standardized } \\
\text { Coefficient }\end{array}$ & $t$-Value $(p)$ & $\begin{array}{c}\text { Status of } \\
\text { Acceptance }\end{array}$ & $\mathbf{R}^{2}$ \\
\hline $\mathrm{H} 1$ & $\begin{array}{l}\text { Functional motive } \rightarrow \text { Active } \\
\text { consumption attitude }\end{array}$ & 0.178 & 2.173 * & supported & \multirow{5}{*}{0.723} \\
\hline $\mathrm{H} 2$ & $\begin{array}{l}\text { Emotional motive } \rightarrow \text { Active } \\
\text { consumption attitude }\end{array}$ & 0.152 & 1.806 & Rejected & \\
\hline H3 & $\begin{array}{l}\text { Social motive } \rightarrow \text { Active } \\
\text { consumption attitude }\end{array}$ & 0.152 & $2.703 * *$ & supported & \\
\hline $\mathrm{H} 4$ & $\begin{array}{l}\text { Epistemic motive } \rightarrow \text { Active } \\
\quad \text { consumption attitude }\end{array}$ & 0.045 & $2.621^{* *}$ & supported & \\
\hline H5 & $\begin{array}{c}\text { Economic motive } \rightarrow \text { Active } \\
\text { consumption } \\
\text { attitude }\end{array}$ & 0.283 & $5.167^{* * *}$ & supported & \\
\hline H6 & $\begin{array}{l}\text { Active consumption attitude } \\
\rightarrow \text { Continuous consumption } \\
\text { behavior }\end{array}$ & 0.201 & $2.089 *$ & supported & 0.718 \\
\hline
\end{tabular}

\section{Conclusions}

\subsection{Finding and Discussion}

The analysis results show that economic factor is the most influential factor among the active consumption attitudes in the limited edition product reselling market. Many studies have been conducted on limited product consumption behavior from the perspective of culture, brand, and emotional motives [21,22,77]. However, previous studies seemed somewhat limited in fully explaining the consumption behavior due to little understanding of consumers' self-reselling and auction behavior in a person-to-person market or customer open market. Bils [78] mentioned that demand movements are partially offset by price response in standard price models. In a customer market, however, price makeups may magnify a customer's psychological traits and social values. Chae et al. [79] point out that the limited edition product consumption is associated with investment, uniqueness, and self-expression. Finally, Kim et al. [80] identified customers' use of limited edition product as being responsible for revealing their identities and image although they view it as investment goods for resale. This shows that limited edition goods are related to a customer's investment motive and sales revenue as with the new word "sneaker tech" which is a personal investment and reselling business of limited edition sneakers in customer open market. Customers of limited edition products expect that products like art works or heritages could resell at a higher price in the market because they are rare or limited, thus allowing them to alter the product price. In addition, current customers can resell their limited edition products by themselves on various online distribution channels. Such economic motivation improves the active consumption attitudes toward limited edition products and leads to continuous consumption and innovative resale behaviors [81,82].

Second, this study indicates that the social motivation of the customers affects their active consumption attitudes to resell limited edition products. With the fast growth of social media as evidenced by Instagram, Twitter, and Snapchat, the outlet of self-expression through rare products and sharing the feeling of possessing those items continues to vary within open culture. As Silverstein and Fiske [83] suggested, the trading-up phenomenon increases a customer's tendency to attain something by consuming products with higher social value and through personal motivation. They consider a reference group in connection to reselling purchases to meet their needs for the purpose of recognition in those groups. Likewise, they partake in social media to announce their possession of high-quality goods which leads to the desire for rare and new products that could differentiate themselves from 
others $[84,85]$. As they buy rare resale products, they feel a sense of belonging and unity to a special community; hence, such customer self-efficacy can lead to active and innovative consumption attitudes.

Third, the motivations of reselling limited product consumption affect economic, social, epistemic, and functional aspects, but do not affect emotional motives. This means that consuming the resale limited edition product can be influenced by rational consumption behaviors instead of the general buying of limited edition products. Many previous studies $[30,86]$ stated that emotional value and motivation are important influences on limited edition and rare goods. However, the results show that the effect of the emotional motivation of consumption behavior can be different between the general limited product market and the reselling open market.

\subsection{Practical Implications}

This study has the following implications. First, the customers in the reselling market of limited edition products seek economic value. Companies should launch unique and rarely released items to increase the product's price value. Recently, many fashion and luxury brands have begun to launch limited edition collaboration products with superstars, celebrities, and influencers. This scarcity message makes consumers feel that limited products are more special, unique, and valuable [30]; thus, a new message strategy is important to create a positive effect on a customer's evaluation of a product.

Second, companies should promote customer open markets for reselling. Growing the reselling markets of limited edition products would lead to new customer inflows, expanding the market size. Moreover, active customers could produce a viral marketing effect of products [86]. For this reason, the promotion strategies related to a customer's consuming and reselling behaviors of limited edition products on the resale distribution platform will be able to attract and retain customers on a continuous basis for the business.

Third, companies could benefit from the community management aspect and resale market trend to catch up with new purchasers and unique business models in the reselling markets of limited edition products. The customers are more interested in expressing themselves through products rather than receiving social recognition. They also want to produce and sell the products by themselves $[87,88]$. In particular, young customers have actively created and led a new sales platform and consumption culture. For these reasons, companies should focus on exploring the customer and market trends for fast changes.

\subsection{Research Limitations and Future Studies}

This study is important because it reveals meaningful effects on the active consumption attitude and consumption motivations of limited edition resale products, but further study is needed due to the research limitations. First, this study was conducted with South Korea as the target country. This could be a limitation of this research because the analysis results were not generated to the whole market status. However, future research may have several countries as the target with reference to the report that the fashion and beauty reselling market is growing in North America, Europe, and Asia to compare the market's different characters. Second, this research uses the five motivation factors based on purchase motivation theories. This point can be a limitation in that this article couldn't consider other effect variables to purchase the limited edition resale products. For this reason, future study should suggest some reselling consumption-affected variables such as genders, ages, and occupations. Lastly, future studies should verify the implications for the direction of the consumption attitude of limited addition resale products by expanding the subjects to different genders, ages, and occupations in order to observe the differences in outcomes.

Author Contributions: Funding acquisition, W.K.; resources, W.K.; supervision, B.K.; methodology, B.K.; writing-original draft, W.K. and B.K.; writing-review and editing, B.K. All authors have read and agreed to the published version of the manuscript.

Funding: This research received no external funding. 
Acknowledgments: This research was supported by aSSIST (Seoul School of Integrated Sciences and Technologies).

Conflicts of Interest: The authors declare no conflict of interest.

\section{References}

1. Tomičić Furjan, M.; Tomičić-Pupek, K.; Pihir, I. Understanding digital transformation initiatives: Case studies analysis. Bus. Syst. Res. 2020, 11, 125-141. [CrossRef]

2. Yun, J.H. Business Model Design Compass: Open Innovation Funnel to Schumpeterian Mew Compbnation Business Model Developing Circle; Springer Nature: Cham, Switzerland, 2017.

3. Castro, I.A.; Morales, A.C.; Nowils, S.M. The influence of disorganized self displays and limited product quantity on consumer purchase. J. Mark. 2013, 77, 118-133. [CrossRef]

4. Cooper, R.G. The drivers of success in new-product development. Ind. Mark. Manag. 2019, 76, 36-47. [CrossRef]

5. Chen, Y.; Lu, Y.; Wang, B.; Pan, Z. How do product recommendations affect impulse buying? An empirical study on WeChat social commerce. Inf. Manag. 2019, 56, 236-248. [CrossRef]

6. Mina, A.; Bascavusoglu-Moreau, E.; Hughes, A. Open service innovation and the firms search for external knowledge. Res. Policy 2014, 43, 853-866. [CrossRef]

7. Gay, B. Open innovation, networking, and business model dynamics: The two sides. J. Innov. Entrep. 2014, 3, 2. [CrossRef]

8. Goncalves, S.M.; de Silva, R.V.; Teixeira, N. Individual actors and embeddedness in business-to-business interactions. Ind. Mark. Manag. 2019, 76, 181-191. [CrossRef]

9. Chandon, P.J.; Hutchinson, W.; Bradlow, E.T.; Young, S.H. Does in-store marketing work? Effects of the number and position of shelf facings on brand attention and evaluation at the point of purchase. J. Mark. 2009, 73, 1-17. [CrossRef]

10. Morales, A.C.; Fitzsimons, G.J. Product contagion: Changing consumer evaluations though physical contact with 'disgusting' products. J. Mark. Res. 2007, 44, 272-283. [CrossRef]

11. Kim, W.D.; Kim, B.Y. The Critical Factors A_ecting the Consumer Reselling of Limited Edition Products: A Case in the Korean Fashion Sector. Sustainability 2020, 12, 8181. [CrossRef]

12. Akaka, M.A.; Vargo, S.L.; Schau, H.J. The context of experience. J. Serv. Manag. 2015, 26, 206-223. [CrossRef]

13. Chandler, J.D.; Vargo, S.L. Contextualization and value-in-context: How context frames exchange. Mark. Theory 2011, 11, 35-49. [CrossRef]

14. Tauber, E.M. Marketing notes and communication: Why do people shop? J. Mark. 1972, 36, 58-70. [CrossRef]

15. Delbridge, R.; Edwards, T. Inhabiting institutions: Critical realist refinements to understanding institutional complexity and change. Organ. Stud. 2013, 34, 927-947. [CrossRef]

16. Ryan, R.M.; Deci, E.L. Brick by brick: The origins, development and future of self-determination theory. Adv. Motiv. Sci. 2019, 6, 111-156.

17. Malaviya, P.; Brendl, C.M. Do hedonic motives moderate regulatory focus motives? Evidence from the framing of persuasive messages. J. Personal. Soc. Psychol. 2014, 106, 1-19. [CrossRef]

18. Dou, X.; Walden, J.A.; Lee, S.; Lee, J.Y. Does source matter? Examining source effects in online product reviews. Comput. Hum. Behav. 2012, 28, 1555-1563. [CrossRef]

19. Goldsmiths, R.; Lafferty, B.; Newell, S. The impact of corporate credibility and celebrity on consumer reaction to advertisements and hands. J. Advert. 2000, 29, 43-54. [CrossRef]

20. Hair, M.; Ozcan, T. How reviewers' use of profanity affects perceived usefulness of online reviews. Mark. Lett. 2018, 29, 151-163. [CrossRef]

21. Hirschman, E.C. Humanistic inquiry in marketing research: Philosophy, method, and criteria. J. Mark. Res. 1986, 23, 237-249. [CrossRef]

22. Petty, R.E.; Wegener, D.T.; Fabrigar, L.R. Attitudes and Attitude Change. Annu. Rev. Psychol. 1997, 48, 609-647. [CrossRef]

23. Roy, R.; Sharma, P. Scarcity appeal in advertising: Exploring the moderating roles of need for uniqueness and message framing. J. Advert. 2015, 44, 349-359. [CrossRef]

24. Bearden, W.O.; Rose, R.L. Attention to social comparison information: An individual difference factor affecting consumer conformity. J. Consum. Res. 1990, 16, 461-471. [CrossRef] 
25. Gierl, H.; Huettl, V. Are scarce products always more attractive? The interaction of different types of scarcity signals with products' suitability for conspicuous consumption. Int. J. Res. Mark. 2010, 27, 225-235. [CrossRef]

26. Simonson, I.; Nowlis, M.S. The role of explanations and need for uniqueness in consumer decision making: Unconventional choices based on reasons. J. Consum. Res. 2000, 27, 49-68. [CrossRef]

27. Ku, H.; Kuo, C.; Fang, W.; Yu, Y. The impact of retail out-of-stock options on preferences: The role of consumers' desire for assimilation versus differentiation. Mark. Lett. 2014, 25, 53-66. [CrossRef]

28. Cheema, A.; Kaikati, A.M. The effect of need for uniqueness on word of mouth. J. Mark. Res. 2010, 47, 553-563. [CrossRef]

29. Lerner, J.S.; Small, D.A.; Lowenstein, G. Heart strings and purse strings: Carryover effects of emotions on economic decisions. Psychol. Sci. 2004, 15, 337-341. [CrossRef]

30. Jang, W.S.; Ko, Y.J.; Morris, J.D.; Chang, Y.H. Scarcity message effects on consumption behavior: Limited edition product considerations. Psychol. Mark. 2015, 32, 989-1001. [CrossRef]

31. La Rocca, A.; Hoholm, T.; Mørk, B.E. Practice theory and the study of interaction in business relationships: Some methodological implications. Ind. Mark. Manag. 2017, 60, 187-195. [CrossRef]

32. Ortiz, J.F.; Corrada, M.S.; Gonzalez, V.D.; Gonzalez, E.L.; Vega, A. Millennials \& Snapchat: Self-expression through its use and its influence on purchase motivation. J. Bus. Res. 2019, 14. [CrossRef]

33. Ali, A.; Xiaoling, G.; Ali, A.; Sherwani, M.; Muneeb, F.M. Customer motivations for sustainable consumption: Investigating the drivers of purchases behavior for a green-luxury car. Bus. Strategy Environ. 2019, 28, 833-846. [CrossRef]

34. Choi, D.Y.; Kim, K.P. Influences of environmental and hedonic motivations on intention to purchase green products: An extension of the theory of planned behavior. Sustain. Prod. Consum. 2019, 18, 145-155. [CrossRef]

35. Kalpana, R.; Shibu, L. Influence of few variables on customer buying behavior. Int. J. Manag. 2016, 7, 387-394.

36. Tanduklangi, A.; Yusuf, H. The role of customer motivation in mediating customer communication and customer decision to use Kartu As of telkomsel broadband Services in Kendari of Indonesia. Int. J. Soc. Sci. 2017, 8, 87-96. [CrossRef]

37. Anitha, N. Influence of lifestyle on customer making with special reference to go organized retail formats in Chennai. Indian J. Commer. Manag. Stud. 2016, 1, 85-91.

38. Wahab, Z. The influence of online shopping motivation and product browsing toward impulse buying of fashion products on a social commerce. Int. J. Sci. Res. Publ. 2018, 8, 402-406.

39. Herawati, S.D.; Kardoyo, W.P. Predicted purchasing decisions from lifestyle, product quality and price through purchase motivation. J. Econ. Educ. 2019, 8, 1-11.

40. Birch, D.; Memery, J.; Kanakaratne, M. The mindful consumer: Balancing egoistic and altruistic motivations to purchase local food. J. Retail. Consum. Serv. 2018, 40, 221-228. [CrossRef]

41. Nwankwo, S.; Hamelin, N.; Khaled, M. Consumer values, motivation and purchase intention for luxury goods. J. Retail. Consum. Serv. 2014, 21, 735-744. [CrossRef]

42. Whitely, S.C.; Trudel, R.; Kurt, D. The influence of purchase motivation on perceived preference uniqueness and assortment size choice. J. Consum. Res. 2018, 45, 710-724. [CrossRef]

43. Tang, M.; Zhu, J. Research of $\mathrm{O} 2 \mathrm{O}$ website based consumer purchase decision-making model. J. Ind. Prod. Eng. 2019, 11, 371-384. [CrossRef]

44. Prentice, C.; Han, X.Y.; Hua, L.L.; Hu, L. The influence of identity-driven customer engagement on purchase intention. J. Retail. Consum. Serv. 2019, 47, 339-347. [CrossRef]

45. Bilro, R.G.; Loureire, S.M.C.; Guerreiro, J. Exploring online customer engagement with hospitality products and its relationship with involvement, emotional states, experience and brand advocacy. J. Hosp. Mark. Manag. 2019, 28, 147-171. [CrossRef]

46. Chernev, A.; Böckenholt, U.; Goodman, J. Choice overload: A conceptual review and meta-analysis. J. Consum. Psychol. 2015, 25, 333-358. [CrossRef]

47. Wan, E.W.; Xu, J.; Ding, Y. To be or not to be unique? The effect of social exclusion on consumer choice. J. Consum. Res. 2014, 40, 1109-1122. [CrossRef]

48. Grönroos, C. A service perspective on business relationships: The value creation, interaction and marketing interface. Ind. Mark. Manag. 2011, 40, 240-247. [CrossRef] 
49. Guercini, S.; La Rocca, A.; Runfola, A.; Snehota, I. Interaction behaviors in business relationships and heuristics: Issues for management and research agenda. Ind. Mark. Manag. 2014, 43, 929-937. [CrossRef]

50. Huang, J.H.; Chen, Y.F. Herding in online product choice. Psychol. Mark. 2006, 23, 413-428. [CrossRef]

51. Zhang, L. Fashioning the feminine self in prosumer capitalism: Women's work and the transnational reselling of Western luxury online. J. Consum. Cult. 2017, 17, 184-204. [CrossRef]

52. Lee, M.; Faber, R.L. Effects of product placement in on-line game on brand memory: A perspective of the limited-capacity model of attention. J. Advert. 2013, 36, 75-90. [CrossRef]

53. Loureiro, S.M.C.; Maximiano, M.; Panchapakesan, P. Engaging fashion consumers in social media: The case of luxury brands. Int. J. Fash. Des. Technol. Educ. 2018, 11, 310-321. [CrossRef]

54. Legendre, T.S.; Jo, Y.H.; Han, Y.S.; Kim, Y.W.; Ryu, J.P.; Jang, S.J.; Kim, J. The impact of consumer familiarity on edible insect food product purchase and expected linking: The role of media trust and purchase activism. Entomol. Res. 2019, 49, 158-164. [CrossRef]

55. Li, Q.; Wang, Q.S.; Song, P.J. The effects of agency selling on reselling on hybrid retail platforms. Int. J. Electron. Commer. 2019, 23, 524-556. [CrossRef]

56. Engel, J.F.; Blackwell, R.D.; Miniard, P.W. Consumer Behavior, 6th ed.; Dryden Press: Chicago, IL, USA, 1990.

57. Kwon, Y.I.; Son, J.K. A case study on the promising product selection indicators for small and medium-sized enterprises. J. Open Innov. Technol. Mark. Complex. 2018, 4, 56. [CrossRef]

58. Saura, J.R.; Reyes-Menendez, A.; Palos-Sanchez, P. Are black Friday deals worth it? Mining twitter users' sentiment and behavior response. J. Open Innov. Technol. Mark. Complex. 2019, 5, 58. [CrossRef]

59. Libai, B.; Bolton, B.; Bügel, M.S.; Ruyter, K.; Götz, O.; Risselada, H.; Stephen, A.T. Customer-to-customer interactions: Broadening the scope of word of mouth research. J. Serv. Res. 2010, 13, 267-292. [CrossRef]

60. Geiger, S.M.; Keller, J. Shopping for clothes and sensitivity for the suffering of others: The role of compassion and values in sustainable fashion consumption. Environ. Behav. 2017, 50, 1119-1144. [CrossRef]

61. Bazhanov, A.; Levin, Y.; Nediak, M. Resale price maintenance with strategic customers. Prod. Oper. Manag. 2019, 28, 535-549. [CrossRef]

62. Valenzuela, A.; Priya, R. Position-based beliefs: The center-stage effect. J. Consum. Psychol. 2019, 19, $185-196$. [CrossRef]

63. Martin, B.A.S.; Jin, H.S.; O'Conner, P.J.; Hughes, C. The relationship between narcissism and consumption behaviors: A comparison of measures. Personal. Individ. Differ. 2019, 141, 196-199. [CrossRef]

64. Li, J.; Guo, S.; Zhang, J.Z.; Sun, L. When others show off my brand: Self-brand association and conspicuous consumption. Asia Pac. J. Mark. Logist. 2019, 32, 1214-1225. [CrossRef]

65. Wong, K.H.; Chang, H.H.; Yeh, C.H. The effects of consumption values and relational benefits on smartphone brand switching behavior. Inf. Technol. People 2019, 32, 217-243. [CrossRef]

66. Pino, G.; Amatulli, C.; Peluso, A.M.; Nataraajan, R.; Guido, G. Brand prominence and social status in luxury consumption: A comparison of emerging and mature markets. J. Retail. Consum. Serv. 2019, 46, 163-172. [CrossRef]

67. Geiger, S.M.; Fischer, D.; Schrader, U. Meditating for the planet: Effects of a mindfulness-based intervention on sustainable consumption behaviors. Environ. Behav. 2019, 52, 1012-1042. [CrossRef]

68. Bilharz, M.; Schmitt, K. Going big with big matters: The key points approach to sustainable consumption. Ecol. Perspect. Sci. Soc. 2011, 20, 232-235. [CrossRef]

69. Geiger, S.M.; Fischer, D.; Schrader, U. Measuring what matters in sustainable consumption: An integrative framework for the selection of relevant behaviors. Sustain. Dev. 2017, 26, 18-33. [CrossRef]

70. Esenduran, G.; Hill, J.A.; Noh, I.J. Understanding the choice of inline resale channel for used electronics. Prod. Oper. Manag. 2020, 29, 1188-1211. [CrossRef]

71. Chu, H.; Liao, S. Toward a conceptual model of consumer online resale behavior: An exploratory study in Taiwan. J. Internet Commer. 2008, 7, 220-252. [CrossRef]

72. Vargo, S.L. Market systems, stakeholders and value propositions: Toward a service dominant logic-based theory of the market. Eur. J. Mark. 2011, 45, 217-222. [CrossRef]

73. Hernaus, T.; Pejić Bach, M.; Bosilj Vukšić, V. Influence of strategic approach to BPM on financial and non-financial performance. Balt. J. Manag. 2012, 7, 376-396. [CrossRef]

74. Bryman, A.; Cramer, D.E.G. Quantitative data analysis for social scientists. Soc. Sci. Q. 1992, 53, 347.

75. Kim, Y.J.; Kim, B.Y. Selection attributes of innovative digital platform-based subscription services: A case of South Korea. J. Open Innov. Technol. Mark. Complex. 2020, 6, 70. [CrossRef] 
76. Muthén, B.O.; Satorra, A. Complex sample data in structural equation modeling. Sociol. Methodol. 1995, 25, 267-316. [CrossRef]

77. Cisek, S.Z.; Sedikides, C.; Hart, C.M.; Godwin, H.J.; Benson, V.; Liversedge, S.P. Narcissism and customer behaviour: A review and preliminary findings. Front. Psychol. 2015, 5, 232-243.

78. Bils, M. Pricing in customer market. Q. J. Econ. 1989, 104, 699-718. [CrossRef]

79. Chae, H.J.; Kim, S.W.; Lee, J.G.; Park, K.H. Impact of product characteristics of limited edition shoes on perceived value, brand trust, and purchase intention: Focused on the scarcity message frequency. J. Bus. Res. 2020, 29, 398-406. [CrossRef]

80. Kim, M.J.; Choi, H.S.; Lee, H.J. A study on the history of western shoes and their aesthetic value. J. Korean Soc. Costume 2001, 51, 157-173.

81. Wu, L.; Lee, C. Limited edition for me and best seller for you: The impact of scarcity versus popularity cues on self versus other-purchase behavior. J. Retail. 2016, 92, 486-499. [CrossRef]

82. Dörnyei, K.R. Limited edition packaging: Objectives, implementations and related marketing mix decisions of a scarcity product tactic. J. Consum. Mark. 2020, 37, 617-627. [CrossRef]

83. Silverstein, M.J.; Fiske, N. Luxury for the masses. Harv. Bus. Rev. 2003, 81, $48-57$.

84. Sheth, J.N.; Newman, B.I.; Gross, B.L. Why we buy what we buy: A theory of consumption values. J. Bus. Res. 1991, 22, 159-170. [CrossRef]

85. Shin, D.H.; Lee, K.A. The Influences that satisfaction of deficiency needs exerts on social media loyalty the interaction between the mediating effect of social media characteristics and anonymity. Form. Media Stud. 2019, 22, 22-34.

86. Graeff, T.R. Using promotional messages to manage the effects of brand and self-image on brand evaluations. J. Consum. Mark. 1996, 13, 4-18. [CrossRef]

87. Tian, K.T.; Bearden, W.O.; Hunter, G.L. Consumers' need for uniqueness: Scale development and validation. J. Consum. Res. 2001, 28, 50-66. [CrossRef]

88. Simmons, C.J.; Lynch, J.G., Jr. Inference effects without inference making? Effects of missing information on discounting and use of presented information. J. Consum. Res. 1991, 17, 477-491. [CrossRef]

Publisher's Note: MDPI stays neutral with regard to jurisdictional claims in published maps and institutional affiliations.

(C) 2020 by the authors. Licensee MDPI, Basel, Switzerland. This article is an open access article distributed under the terms and conditions of the Creative Commons Attribution (CC BY) license (http://creativecommons.org/licenses/by/4.0/). 